\title{
Multiculturalism and Indonesian Identity Strategy in Indonesian Literature Study
}

\author{
I Nyoman Suaka \\ Indonesian Language and Literature Education Department, Teachers Training College Saraswati Tabanan Bali
}

\begin{abstract}
This article examines the Indonesian problem which contains of different religion, culture, language, ethnicity and politics. This diversity often becomes a source of conflict triggering SARA (Tribe, Religion, Race, intergroup). The problem in this research is what the strategy used to avoid the racial conflict. This is a qualitative research using literature documents as the objects. Documents such as Indonesian novels were analyzed to determine the role of Indonesian literature in supporting multiculturalism. The results showed that Indonesian literature itself already reflects the multicultural nature of regional identity in Indonesia such as Sumatra, Java, Bali, Kalimantan, Papuan and others.
\end{abstract}

Keywords: multiculturalism, Indonesia, Literature

\section{Introduction}

Anticipating the problems, bureaucrats raises term of SARA (Tribe, Religion, Race and intergroup). In "Orde baru" era, hearing this term was quite scary because of strong government intervention. In the reform era, ethnic and religious issues are often the source of conflict. These problems require alternative solutions. It is time for these Issues of race, religion and cultural potential of the region to put forward. Regional culture that has been recognized as national culture should be valued on an ongoing basis. This can be done through the Indonesian literature which is very rich in ethnic culture. It can facilitate our understanding of the problems as the Indonesian literary works use bahasa Indonesia, the national language as the medium.

This paper tries to present an idea of multiculturalism through the appreciation of the work of modern Indonesian literature. Indonesian literary tradition is built on ethnic identities spreading across the archipelago. Modern Indonesian literature, although playing at the level of the imagination, in fact it reflects community cultural facts. It is a representation of facts and fiction. The literary work is a reflection on the life around its writer, so it cannot be separated from the socio-cultural context of the community. This cultural context, directly or indirectly, will go towards an estuary called Indonesia multicultural. Modern Indonesian literature is expected to be a model or strategy toward the understanding of the multicultural society.

Literary works such as the novel "warisan"by Chairul Harun, used the Minangkabau culture. Javanese culture was expressedin the novel Gadis Pantai (Pramoedya Ananta tour). Sundanese culture can be seen in the work of Ajip Rosidi, "Perjalanan Penganten". Balinese culture on "Tarian Bumi" and "Sagra" (Oka Rusmini). Kalimantan culturein "Ceremony"novel by Korrie Layun Rampan, and Papua culture can be seen in "Namaku Teweraut". Appreciating those literary works is the entrance towards the understanding of multiculturalism. This can be done through education on multicultural-based literature. The idea of multicultural education is something new in Indonesia, along with the messy social, political, cultural condition since the reform era. Therefore it is suggested that people appreciate literature works as an afterthought towards a high tolerance multicultural Indonesian society.

Regarding the above issues and as the effort to multicultural society, understanding and analyzing Indonesian literature are necessary. Indonesian literature in the form of novel has reflected the diverse conditions in Indonesia. However, it is not widely known by the public considering the readers of literary works are relatively few. Therefore, the discussion in this paper examines the ethnic cultures in Indonesian literature. From that perspective, it is the expected to get a picture that Indonesian literature culture is a mean to strengthen the sense of unity within the framework of the multicultural Indonesian nation.

\section{Discussion}

\subsection{Ethnic Identity in Literature.}

According to the Mahayana (2003), culturally, modern Indonesian literature at first is ethnic literature written in Indonesian language, the national language adapted from the Malay ethnic language. As literature which its spirit came from ethnic cultures, it was not dependently free from things around it. At least it wasn't far from the writer's life which cannot be separated from ethnic backgrounds.

In line with that statement, Esten (1988: 12) states, an Indonesian writer is artist of two worlds. Cultural world and new world Indonesia. The cultural values from where the writer comes with the basic proposed thoughts will affect the works. Mahayana and Esten statements are clearly visible until now, both in novels published by Balai Pustaka, as well as novels published recently. However, recently, works are not only showing the ethnic culture but also collaborating with national and global culture.

Some novel representing ethnic culture has enriched the diversity of Indonesia as a novel about the Minangkabau ethnic heritage Chairul works Arun, Javanese culture express the novel The Priyayi (Omar Khayyam), Ronggeng Dukuh Paruk (Ahmad Tohari), Beach Girl (Pramoedya Ananta tur). Sundanese culture at Family Permana Ramadhan KH, and Travel Penganten ajip rosidi work. Bali 


\section{International Journal of Science and Research (IJSR) \\ ISSN (Online): 2319-7064 \\ Index Copernicus Value (2013): 6.14 | Impact Factor (2015): 6.391}

culture at Night When Night Goes (Putu Wijaya), Tariam Earth and Sagra (Oka Rusmini). Kultur Kalimantan, the novel Ceremony Korrie Layun Rampan work, and culture of Papua looked at the novel My Name Teweraut. To reflect the ethnic culture in such works should be studied several novels in this description to prove Indonesia as a multicultural country.

"Warisan" novel set in Minangkabau was no longer dwell on the problems of custom and tradition as expressed in the novels published by Balai Pustaka. Arun Chairul works, discusses the very peculiar "Haro Pusako". According to local culture, this issue should be settled between a "mamak" with her nephew. Finally, this problem could be solved by a young leader Rafilus by reflecting on the elements of global culture Minang community is known to have a unique culture because they adhere matrilineal kinship system. Their people are known to revere the culture of their ancestors. The Author told us about the conflict of the inheritance division. The position of woman in Minang culture was crucial to inherit the inheritance, either it was high or low inheritance. Along with the evolution of culture, norms and religious values started to shift. Some things which did not change in this novel were social system that governed inheritance, habits of buying men and has a lot of wives.

The will given by Tahar Bagindo in this novel "Warisan" as the tradition side to Rafilus as the modernization side can be interpreted as a recommendation for the issue of dividing inheritance could be done by another family other than a "mamak". According Novalina (2004: 27), it was act beyond tradition Kuraitaji. It was a new thoughtfrom the author to break down and to get out from the tradition that had been prevailing in the society.

Cultural evolution was also found in the novel "Perjalanan Penganten"a works of Ajip Rosidi set in Sundanese. Implicitly, there were cultural changes undertaken by some people that shifted from the tradition embraced by their ancestors. Kuntjaraningrat (1980: 101) mentioned the culture evolution as a cultural development from a very simple form to the very complex form. The author managed to capture the attitude, outlook on life and behavior of Sundanese culture. A clear picture of the Sundanese ethnic can be seen when figure AKU traveledto return to his hometown in Jatiwangi. The life of Aku getting education in the city, working in the city, mingling with the life in metropolitan city of Jakarta, was possible for the evolution to occur.

This figure began to forget some of the traditional values if not reminded by his relatives in the village. Aku's attitude in facing all rituals, customs and traditions showed that he just did them only because his parents were doing them before. He did not appreciate and understand the significance of the ritual. Instead, he tried to break away from this tradition. He married with compulsion. He was feeling as stranger in the tradition he lived. However, he realized that it was a ritual that he must be lived with. His indifference was influenced by the situation where hung out in Jakarta.
The same thing is also implicit in the novel "Upacara" by Korri Layun Rampan set in the Dayak community in Kalimantan Outback. We are required to be extra careful reading this novel, let alone if we have different cultural background. The novel attempts to tell about the Dayak community that could not be separated from ceremony. Life was a stage filled with grain ceremony for ceremonial purposes. This condition, for today's generations, became a complex and exhaustingphenomenon. Fidelity to the tradition was regarded as the belief itself. When people failed do the ceremony, the result would be catastrophe (plague). This novel leads us to the multicultural.

Various ceremonies were depicted in this novel, starting from the wandering spirits "Aku" on its way to heaven (lumut). This odyssey was a healing ceremony for the Aku character. Readers were also invited to see the ceremony balian (shamanism) in search of lost soul from the figure Aku. Moreover, It also presented a Kewangkey ceremony, a ritual that was presented in very vivid descriptions. Burial of human bones had become part of their rites, because they feel in a great debt when their deceased relatives had not been Kewangkeyed yet. After that there was also the party called "nalin taun", which is an annual party as an offering to the gods to prevent the village from all the evil. This novel also depicted pelulung ceremony (marriage ceremony) when Aku figure ended his bachelor. With so many rituals being described by the author, it is decent to this novel to be entitled "Upacara".

Many Javanese cultureswere uncovered in novels by Ahmad Tohari, Omar Khayyam, Kuntowijoyo and Pramoedya Ananta Tur. Given the limited opportunity, only two novels will be mentioned in this paper, Gadis pantai by Pramoedya Ananta Toer and Ronggeng Dukuh Paruk by Ahmad Tohari. According to Pramoedya, gads Pantai novel is and adaptation of true story happened to her grandmother. So even it was an imaginative work, the 1960s novel departed from real life (Haryato, 2007: 214).

Reading Gadis Pantai, it would be found the conflicts between two classes in society, the poor against the noble (bendoro). The conflict was triggered by the oppression of the poor by bendoro. Conflicts expressed by Pramoedya questioned more on the role of religion. Pramoedya saw that religion was more in favor for the authorities and unable to protect ordinary people. The non-devout poor was against the devout bendoro.

Based on Javanese culture (keraton), this novel told about the journey of a beach girl who was proposed by a bendoro to become concubine. For three years, the girl (without mentioningher name), served all bendoro's desire from accompanying the meal time to the bed time. After giving birth to a daughter, the beach girl was divorced by her husband (bendoro) and was returned to her parents. In return she was given quite a lot of money and treasures. The child became full rights of Bendoro's family. The Mother (girl beach) has no right at all for her baby.

In presenting this story, Pramoedya positioned beach girl as the oppressed protagonist, while bendoro was the antagonist, cruel and oppressive. The pious Bendoro oppressingthe non- 


\section{International Journal of Science and Research (IJSR) \\ ISSN (Online): 2319-7064}

Index Copernicus Value (2013): 6.14 | Impact Factor (2015): 6.391

devout beach girl was reflected something paradoxical. The paradoxical wasin the form of oppression by religious people to the beach girl, she was his wife, as well as when she was divorced. According to the analysis Haryato (2007) there were four types of oppression in this novel: (1) forcingthe beach girl to become concubine, (2) making the beach girl only as an object of sex, (3) not admittingthe beach girl as his wife before journalists, and (4) divorcing the beach girl without feeling guilty by giving severance pay.

Based on those sins, Haryato in his article entitled, " Potret Impotensi Agama dalam novel Gadis Pantai," concluded that the novel Gadis Pantai shows the message that religion was powerless to eradicate oppression of the nobles. Through this novel, Pramoedya, confirmed his view that in feudal systemreligion was not in favor of the rabble. In this case, religion was not able to raise the dignity of women. Religion even acted as a legitimate tool by bendoro to oppress women. (Depdiknas, 2007. Dua Puluh Enam Naskah Terbaik).

However, as a literary work, the novel still contributes to human values. Satire stated by the author can be used as food for thought for the readers, given in reality it is still relevant to the present era and the future. Obedience on religious teachings and practices should be followed by religious values for the welfare of mankind. In the end she refused to return to her village. He went to Blora and always visited Bendoro's yard. It was a form of resistance, since in those dayswomen generally did not dare to do what she did. Disclosure of the traditional values of Java is also narrated by the author Ahmad Tohari in Ronggeng Dukuh Paruk (1982). Ronggeng Dukuh Paruk (RDP) novel tells about the life of a ronggeng named Srintil in Dukuh Paruk, a small hamlet in the village of Tinggar Jaya, Lawang Jati subdistrict, Banyumas regency, Central Java. In Dukuh Paruk, ronggeng was not only a form of art, but also a symbol of social status and the spirit of life which was sacred. This novel became famous after being transformed into a form of movie entitled Sang Penari. One of the strengths of this film was the emergence of political events $\mathrm{G} .30 \mathrm{~S}$ in the novel but was not so visible to the reader.

Dukuh Paruk communitiy in Banyumas, Central Java assumed that the population will be stricken without a ronggeng. Even one resident of Dukuh Paruk, did not want to die before bertayub (dancing) with the dancers. This proved how strong the value of ronggeng traditions handed down by their ancestors, Ki Secamenggala. Dukuh Paruk community would feel a big sin if they could not sustain ronggeng. Ki Secamenggala would be enraged in the grave if their offspring could not preserve the arts of ronggeng.

Javacommunity, especially in Central Java, has long recognized ronggeng arts. However ronggeng in Dukuh Paruk, was an event that was very distinctive and important. In the hamlet, a woman who would become a ronggengdancer should be good in nembang, dancing and must underwent three phases of ceremony. The three phases were, 1). Submission and approval of ronggeng candidate as daughter of a shaman ronggeng, 2). Cleansingof ronggeng in front of ancestral graves, and 3). Bukak klambu ceremony,a ceremony of giving away her virginity by having competition.

\subsection{Women's Image}

Balinese Cultures was lately discussed by female author, Oka Rusmini, as seen in the novel Tarian Bumi, and Sagra, (a collection of short stories). Her works presented feminist movement. This young author burnt the spirit of women which implied two things. First, the form of resistance to her mother by Sagra was a representation of resistance of the young against the old. The young woman, with the progress of time and education, sought to awaken the elderly to align themselves, without much tied to the tradition of oldfashioned and quaint. Second, behind it also implied the process of women democratization.

Oka Rusmini seeks for women's rights in Bali that had been oppressed under the power of men. According to analysis of Nyoman Tingkat (2007: 66) on Sagra, Jaba women (Sudra) were positioned under hegemony of male griya (royalty). The symbol of nobility dismantled by Oka Rusmini was a struggle to deconstruct castes in Balinese society and a move towards multicultural. The deconstruction felt exhausting by conducting recounts that weaking griya, upholding the periphery (Sudra). The woman figure of Shudra became pivotal in the story.

Story to raise the image of women was also observed in the novel Namaku Teweraut by Ani Sekarningsih. Namaku Teweraut novel has Asmat ethnic background, thus become rare work in the ranks of Indonesianliterature that took setting in Papua. The story was about a woman named Tewer. As a tribal woman, her life was far from modern civilization. He experienced social conflicts when in contact with the advancement of technology. It was increasingly felt when Tewer got an opportunity to fly abroad as an art ambassador of the region. From that experience, lots of things could be criticized by Tewer in struggling to life in her village.

Asmat tribe is one of the tribes that inhabit the southwest coast of Papua province. This tribe lives in very remote areas and still covered by the treacherous terrains, because of they are swampy, muddy and covered with tropical forests. They have the belief that the universe is inhabited by spirits and genies, which are called the devils. They also believe in the power of magic, mostly in the form of taboos or restrictions. Tewer was born from a respectable Asmat family. As a woman, she grew up in a neighborhood that glorifies masculinity as a symbol of war, virility and conquest.

This Tewer character highly desired the region could be like the America. The terrain is rich in natural resources and can be built like in America. However, doubts appear in her hearts when looking at the people who are always bound by tradition and custom. Those customary rules would not support the development. This novel revealed traditional wisdoms, regional cultures that were still upheld by the Asmat people. Asmat identity was still maintained amid the progress of the times in this novel. As a woman, this Tewer was like Raden Ajeng Kartini who fought for the 


\section{International Journal of Science and Research (IJSR) \\ ISSN (Online): 2319-7064 \\ Index Copernicus Value (2013): 6.14 | Impact Factor (2015): 6.391}

emancipation of women in the region. He wanted women in the village could think forward like other women in other areas.

\subsection{Multicultural Understanding}

The term of multiculturalism began to dominate public discourse in Indonesia in early 2000s as a result of the economic crisis, the eruption of violent inter-ethnic conflicts and separatist movements in Indonesia. Before the term of multiculturalism became popular in public and academic discourse, the term widely used was pluralism (Putra, 2008: 120). In cultural context, multiculturalism could mean, "more than one cultural identity in one society (Hardjana, 2003: 2).

In his book Contemporary of Social Science A Multicultural Approach, Bryan Fay (in Putra, 2008: 121-122) emphasizes three conditions of multiculturalism, namely the interaction (interaction) between groups, transparency (openness) and learning (learning). In multiculturalism there is no resistance. In this case, the Indonesian literary works, such as the above description, are products of a multicultural society. This can be seen in terms of the origin, form, language and content of the story. Those novels show the spirit of multicultural embedded and reflected in the literary world. The multicultural spirit is a reflection of multicultural reality in Indonesian society.

Those novels above, at least has led to Indonesian multicultural understanding. Of course there are a lot of authors and other works that have not been mentioned also show the diversity of Indonesia. Indonesia literary works are very relevant to be studied to unravel the condition of Indonesia's diverse. Ethnic, cultural and religious diversityreflected in the form of novel Warisan, Perjalanan Penganten, Gadis Pantai, Upacara, Sagra, Namaku Teweraut, is a portrait of ethnicity in this country. Through reading these novels we will be able to cultivate national attitude as a multicultural region. This supports the notion that modern Indonesian literature is uniformity in diversity. Uniformity, because it uses the Indonesian language as a medium of expression, while diversity as the theme of modern Indonesian literature and ethnic problems in the country.

Diversity is a reality in Indonesia that must be managed creatively and innovatively. According to Suparta (2008: 154-155) one of the way is instill positive values and manage them through education by packaging it with multicultural-based education. With multicultural basis, students need to be encouraged to see the value of other cultures, so they have a deep understanding and finally able to appreciate them. The model is not by hiding other cultures, or uniformity of the various cultures into one national culture, so that the local culture is lost but, based on multicultural education, every culture will be recognized of its own truth and value.

\section{Conclusion}

Novels mentioned above have become literary treasures as well as the cultural treasures of Indonesia. Literature in this case is able to contribute, entertain, educate and sometimes satirize problems of local culture awareness towards improving the fate of their characters. Thus, it should be considered for conditioning of Indonesian literature as a strategy towards multicultural understanding. One of model for multiculturalism strategy is through education of Indonesian literature ranging from primary, secondary to college.

The idea of multicultural education in Indonesia is something new. Discussion and literature on the subject is very limited. On the other hand, cultural realities and recent social, political and cultural developments are full of social, political and conflict turbulent in various levels of society. This makes the multicultural education through literary education was increasingly needed.

Basically, multicultural education is education that respects and upholds the diversity of cultures in Indonesia, which consists of many tribes, religions, races and cultures. A brief review of those novels above is sufficient to prove that Indonesian literature is the medium of learning as well as education strategy towards multicultural understanding of Indonesian society.

\section{References}

[1] Dako, Kasmuning. 2007. "Perjalanan Penganten : Simbol Evolusi Kebudayaan." Dalam 26 Naskah Terbaik. Jakarta : Depdiknas.

[2] Esten, Mursal. 1988. Sastra Jalur Kedua. Bandung : Angkasa

[3] Harjana, Andre. 2003. "Pendidikan Multikultural dalam Perspektyif Budaya." Makalah pada Seminar Pendidikan Multikultural dan Hukum Adat dalam Perspektif Budaya. Departemen Kebudayaan dan Pariwisata. Depdiknas Bogor, 18-20 Desember 2003.

[4] Haryoto. 2007. "Potret Impotensi Agama dalam Novel Gadis Pantai." Dalam 26 Naskah Terbaik. Jakarta : Depdiknas

[5] Koentjaraningrat. 1999. Manusia dan Kebudayaan Indonesia. Jakarta : Djambatan.

[6] Mahayana, Maman S. 2003. "Memahami Kebudayaan Etnis Melalui Kesusastraan Indonesia." Denpasar : Jurnal Ilmu-ilmu Budaya Poestaka, Fakultas Sastra Unud.

[7] Novalina. 2004. "Nilai Tradisi dan Modernisasi dalam Novel Warisan karya Chairul Harun," dalam Setangkai melati di Sayap Jibril. Jakarta : Depdiknas

[8] Pilliang, Yasraf Amir. 2003. "Konsep Hetronomi sebagai Strategi Kultural Otonomi Daerah Perbandingan." Denpasar : Jurnal Ilmu-ilmu Budaya Poestaka, Fakultas Sastra Unud.

[9] Putra, I Nyoman Darma. 2008. Bali dalam Kuasa Politik. Denpasar : Arti Foundation.

[10] Rusmini, Oka. 2004. Sagra. Magelang : Indonesiatera.

[11] Rusmini, Oka. 2004. Tarian Bumi. Magelang : Indonesiatera.

[12] Rosidi Ajip 2004. Perjalanan Penganten. Jakarta : Pustaka jaya.

[13] Suparta, Mundzier. 2008. Islamic Multicultural Education. Jakarta : Al Ghazali. 


\section{International Journal of Science and Research (IJSR) \\ ISSN (Online): 2319-7064}

Index Copernicus Value (2013): 6.14 | Impact Factor (2015): 6.391

[14] Sekarningsih, Ani. 2000. Namaku Teweraut. Jakarta : Gramedia.

[15] Setyowardani, Eko. 2007. "Manusia Menggenggam Budaya (Ulasan Novel Upacara karya Korri Layun Rampan)" dalam 26 Naskah Terbaik. Jakarta : Depdiknas.

[16] Tingkat, I Nyoman. 2007. "Sagra : Perempuan yang Mendobrak Tembok Feodal. Dalam 26 Naskah Terbaik. Jakarta : Depdiknas.

[17] Toer, Pramoedya Ananta. 2009. Gadis Pantai. Jakarta: Lentera Dipantara.

\section{Author Profile}

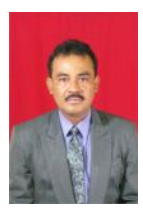

Dr. I Nyoman Suaka, M.Si. did S1 Indonesian Literature of Udayana University, S2 Cultural Study of Udayana University. S3 Cultural Study Udayana University. Dr. I Nyoman Suaka is Kopertis Lecturer at 8th district Denpasar, working at Teachers Training College Saraswati Tabanan Bali teaching Indonesian Language and Literature Education Department, Teachers Training College Saraswati Tabanan Bali. Since 2010 until now is serving as Dean of Faculty of Languange and Art Education, Teachers Training College Saraswati Tabanan Bali 